\title{
Epigenetic evidence of malignant carcinoma and skin melanoma neoplasms concomitantly in the thyroid
}

\author{
Ali Al-Harake ${ }^{1}$, Israa Dandache ${ }^{2}$, Hiba Moukadem ${ }^{3}$, Marwan Saliba ${ }^{4}$, Jimmy Chahine ${ }^{1}$, \\ Hosni Yazbeck ${ }^{4}$, Fadi Abdel-sater ${ }^{5}$, Hussein Karnib ${ }^{4}$, and Mahmoud Younes ${ }^{4}$ \\ ${ }^{1}$ Department of Surgery, Al Rassoul Al Aazam Hospital, Beirut, Lebanon \\ ${ }^{2}$ Department of Life and Earth Sciences, Faculty of Sciences I, Lebanese University, Beirut, \\ Lebanon \\ ${ }^{3}$ Department of Oncology, Saint George Hospital, Baabda, Lebanon \\ ${ }^{4}$ Medical Research Center, Al Rassoul Al Aazam Hospital, Beirut, Lebanon \\ ${ }^{5}$ Department of Biochemistry, Faculty of Sciences I, Lebanese University, Beirut, Lebanon
}

March 23, 2021

\begin{abstract}
The study investigates the case of a total thyroidectomy, where after dissection multiple nodules showed two malignant patterns by immunohistochemistry. Molecular analysis based on DNA methylation profile was used to further inspect the origin of the coexisting neoplasms. We confirmed the presence of malignant skin melanoma involving medullary thyroid cancer.
\end{abstract}

\section{Hosted file}

Case report_2021.pdf available at https://authorea.com/users/403551/articles/514959epigenetic-evidence-of-malignant-carcinoma-and-skin-melanoma-neoplasms-concomitantlyin-the-thyroid

\section{Hosted file}

Figure 1.pdf available at https://authorea.com/users/403551/articles/514959-epigeneticevidence-of-malignant-carcinoma-and-skin-melanoma-neoplasms-concomitantly-in-the-thyroid

\section{Hosted file}

Figure 2.pdf available at https://authorea.com/users/403551/articles/514959-epigeneticevidence-of-malignant-carcinoma-and-skin-melanoma-neoplasms-concomitantly-in-the-thyroid

\section{Hosted file}

Figure 3.pdf available at https://authorea.com/users/403551/articles/514959-epigeneticevidence-of-malignant-carcinoma-and-skin-melanoma-neoplasms-concomitantly-in-the-thyroid 